\title{
Exploiting Issatchenkia orientalis SD108 for succinic acid production
}

\author{
Han Xiao ${ }^{1 \dagger}$, Zengyi Shao ${ }^{1 \dagger}$, Yu Jiang ${ }^{1,2}$, Sudhanshu Dole ${ }^{3}$ and Huimin Zhao ${ }^{1,4^{*}}$
}

\begin{abstract}
Background: Recent advances in synthesizing valuable chemicals such as organic acids from low-cost renewable biomass through microbial fermentation have attracted great attention. However, the toxicity of organic acids presents a key challenge to the development of an economically viable fermentation process. Therefore, a platform organism that not only produces organic acids but also tolerates the associated toxicity is highly desirable.

Results: Here we report the discovery, characterization, and engineering of a yeast strain, Issatchenkia orientalis SD108, that is tolerant to low pH and high concentration of organic acids. This strain demonstrated a higher tolerance compared to I. orientalis ATCC 24210 and Classic Distiller's Turbo yeast. In order to explore SD108 as a potential platform organism for organic acid production, we determined its draft genome sequence and use the sequencing information to guide pathway design. As proof of concept, an engineered four-gene expression cassette related to the reductive TCA cycle was assembled and integrated into the genome of a uracil auxotroph of SD108. The resulting strain was able to produce succinic acid with a titer of $11.63 \mathrm{~g} / \mathrm{L}$, yield of $0.12 \mathrm{~g} / \mathrm{g}$, and productivity of $0.11 \mathrm{~g} / \mathrm{L} \cdot \mathrm{h}$ in batch cultures using shake flasks.

Conclusions: The high tolerance of I. orientalis SD108 towards multiple important organic acids makes it a highly attractive organism as a platform host for producing this group of compounds as it will reduce production cost, facilitate downstream processing, and serve as a host for construction of production strains with both $\mathrm{pH}$ and specific anion tolerance.
\end{abstract}

Keywords: Succinic acid, Acid tolerance, Issatchenkia orientalis, Metabolic engineering

\section{Background}

Largely owing to the concerns with sustainability, global climate change, and energy security, the use of microorganisms to convert renewable biomass to fuels and chemicals has become increasingly attractive. In 2004, the US Department of Energy (DOE) described twelve platform chemicals that could be produced from renewable biomass in a biorefinery, eight of which were organic acids [1]. The wide application of organic acids as platform chemicals, alongside the relatively few enzymatic steps required for their production, has led to intensive investigation into their microbial synthesis. One example is succinic acid, which is a precursor of many industrially

\footnotetext{
*Correspondence: zhao5@illinois.edu

${ }^{\dagger}$ Equal contributors

'Department of Chemical and Biomolecular Engineering, University of Illinois at Urbana-Champaign, Urbana, IL 61801, USA

${ }^{4}$ Departments of Chemistry, Biochemistry, and Bioengineering, Institute for Genomic Biology, University of Illinois at Urbana-Champaign, Urbana,

IL 61801, USA

Full list of author information is available at the end of the article
}

important chemicals such as 1,4-butanediol, tetrahydrofuran, $\gamma$-butyrolactone and various pyrrolidinone derivatives [2]. Other organic acids of interest include itaconic acid, adipic acid and acetic acid. The major applications of itaconic acid include the use as a copolymer with acrylic acid and the conversion to many commodity and specialty chemicals including pyrrolidones and 2-methyl-1,4-butanediol [1]. Although they are not among the twelve platform chemicals, adipic acid is a key C6 dicarboxylic acid ingredient in the production of nylon 6,6 and thermoplastic polyurethanes, and has an annual market of $\$ 6.3$ billion [3], whereas acetic acid is one of the common inhibitors present in lignocellulose hydrolysates, which can lead to severe growth inhibition even at low concentrations [4].

For an economically viable process, a platform organism that not only produces a high level of target organic acid but also tolerates the associated toxicity is highly desired [5]. Recently, we isolated a yeast strain, named as SD108, and identified it as Issatchenkia orientalis by DNA sequencing of its $26 \mathrm{~S}$ ribosomal RNA genes. Due 
to its ability to grow at low $\mathrm{pH}, I$. orientalis has been used in ethanol fermentation at $\mathrm{pH} 2$ [6] and could grow on the saccharification products hydrolyzed from lignocellulosic biomass by sulfuric acid [7]. Cargill Inc. (Wayzata, $\mathrm{MN}$ ) also used I. orientalis for lactic acid production in unbuffered cultures and obtained production rates and yields similar to those of traditional bacterial lactic acid processes [8]. With its potential as a platform organism to produce organic acids, further investigation of this organism is needed.

In this study, we provide a biochemical characterization of $I$. orientalis SD108 and demonstrate that this strain has an extremely high tolerance towards multiple organic acids identified by DOE as platform chemicals. In addition, we determined the draft genome sequence of SD108 via 454 de novo sequencing, offering a resource not only for gaining further insights into the properties of this organism, but also for designing strategies to alter its metabolism for production of chemicals. As proof of concept, four genes from the reductive TCA pathway were assembled and integrated to the genome of a uracil auxotroph strain of $I$. orientalis SD108. The resulting strain exhibited significantly improved titer, yield and productivity of succinic acid production. These results suggest SD108 is a promising host for industrial production of organic acids.

\section{Results}

Characterization of sugar utilization by I. orientalis SD108 The basic features of I. orientalis SD108 as a potential platform organism were first investigated. Batch cultures using shake flasks were performed at $30^{\circ} \mathrm{C}$ in synthetic complete (SC) medium under oxygen-limited condition. I. orientalis SD108 can ferment fructose as efficiently as glucose (Figure 1 and Additional file 1: Figure S1). The maximal specific growth rates of SD108 on $5 \mathrm{~g} / \mathrm{L}$ of glucose and $5 \mathrm{~g} / \mathrm{L}$ of fructose were $0.62 \mathrm{~h}^{-1}$ and $0.65 \mathrm{~h}^{-1}$ respectively (Additional file 1: Figure S1). Shake flask culture profiles of SD108 were further determined using $50 \mathrm{~g} / \mathrm{L}$ glucose and $50 \mathrm{~g} / \mathrm{L}$ fructose as carbon source, respectively. As shown in Figure 1A, SD108 was able to consume all the glucose within $24 \mathrm{~h}$. The titer of glycerol was below $2 \mathrm{~g} / \mathrm{L}$. Acetic acid was not detected during most of the shake flask culture, except for $0.36 \mathrm{~g} / \mathrm{L}$ at $24 \mathrm{~h}$. An ethanol yield of $0.31 \mathrm{~g} / \mathrm{g}$ glucose was achieved after $24 \mathrm{~h}$. With fructose as the sole carbon source, the shake flask culture profile was similar to that with glucose. An ethanol yield of $0.24 \mathrm{~g} / \mathrm{g}$ fructose was achieved after $24 \mathrm{~h}$, which was $23 \%$ less than that of glucose (Figure 1A and B). In addition to glucose and fructose, other sugar components found in different types of biomass substrates including xylose, arabinose, cellobiose, galactose and sucrose [9-12] were tested as potential carbon sources. No consumption of these sugars was observed both at low $(5 \mathrm{~g} / \mathrm{L})$ and high $(50 \mathrm{~g} / \mathrm{L})$ concentrations.

\section{Tolerance towards organic acids}

The $\mathrm{pH}$ range and optimum $\mathrm{pH}$ for growth of strain SD108 were first examined from $\mathrm{pH} 0$ to 6 using $50 \mathrm{~g} / \mathrm{L}$ of glucose as carbon source. While it did not exhibit growth at $\mathrm{pH} 0$ and 1, a wide optimum $\mathrm{pH}$ range of this strain was observed between $\mathrm{pH} 3$ and 6, with a maximum specific growth rate of $0.67 \mathrm{~h}^{-1}$ (Figure 2 and Additional file 1: Figure S2). Given that the pKa values for most building block organic acids range from 3 to 5, the $\mathrm{pH}$ of a fermentation culture is expected to decrease to around 2.0 for acid titers of $50 \mathrm{~g} / \mathrm{L}$. The resultant acidity would possibly have little effect on cell growth of this strain.

To evaluate the organic acid tolerance of SD108, four organic acids were selected: succinic acid, itaconic acid, adipic acid, and acetic acid. Cell growth of SD108 in the presence of different concentrations of these organic acids was analyzed. To eliminate initial $\mathrm{pH}$ discrepancies between these organic acids, all the starting $\mathrm{pH}$ values were adjusted to 5.6, which is in the optimal $\mathrm{pH}$ range of this strain (Figure 2). As shown in Figure 3, the $\mathrm{OD}_{600}$ values of SD108 after $10 \mathrm{~h}$ were greater than the initial value of 0.2 under all the tested conditions. Finally, $30 \mathrm{~g} / \mathrm{L}$ of succinic acid, $30 \mathrm{~g} / \mathrm{L}$ of itaconic acid, $23 \mathrm{~g} / \mathrm{L}$ of adipic acid and $20 \mathrm{~g} / \mathrm{L}$ of acetic acid, under which concentrations SD108 exhibited clear growth, were selected for further analysis (Figure 3).

In order to gauge the organic acid tolerance performance of SD108, another strain of I. orientalis, I. orientalis ATCC 24210, and a fast-growing industrial yeast, Classic Distiller's Turbo yeast, were chosen for comparison. Classic Distiller's Turbo yeast exhibits higher tolerance towards multiple alcohols and inhibitors contained in lignocellulose hydrolysates (e.g., ethanol, n-butanol and furfural) than a series of Saccharomyces cerevisiae laboratory strains including $S$. cerevisiae W303a, S. cerevisiae BY4741 and S. cerevisiae CEN.PK 113-7D (data not shown). No significant difference in the lag phase was found among these three strains in the presence of various organic acids, although the lag phase of the strains in the presence of $30 \mathrm{~g} / \mathrm{L}$ of succinic acid or $30 \mathrm{~g} / \mathrm{L}$ of itaconic acid was 6 hours longer than those observed in $23 \mathrm{~g} / \mathrm{L}$ of adipic acid or $20 \mathrm{~g} / \mathrm{L}$ of acetic acid (Figure 4). As shown in Table 1, the maximum specific growth rates of both I. orientalis ATCC 24210 and SD108 were 0.65 $\mathrm{h}^{-1}$ in the cultures without any supplemented organic acid, which are $12 \%$ higher than Classic Distiller's Turbo yeast. SD108 exhibited maximum specific growth rates of $0.37,0.43,0.58$ and $0.55 \mathrm{~h}^{-1}$ in the cultures with 30 $\mathrm{g} / \mathrm{L}$ of succinic acid, $30 \mathrm{~g} / \mathrm{L}$ of itaconic acid, $23 \mathrm{~g} / \mathrm{L}$ of adipic acid and $20 \mathrm{~g} / \mathrm{L}$ of acetic acid, respectively. These 

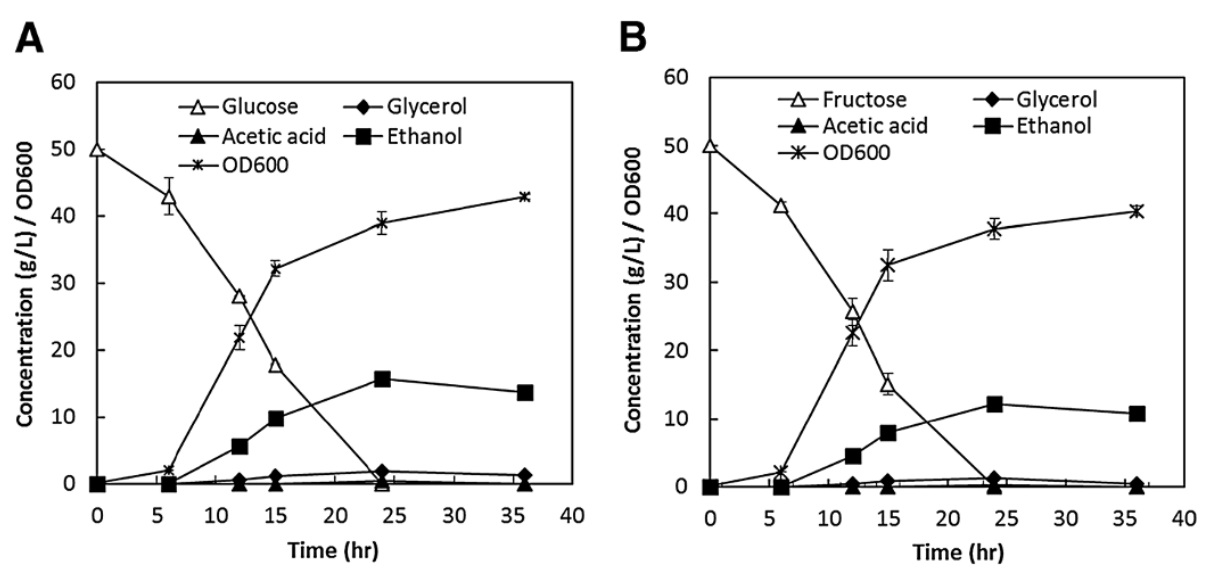

Figure 1 Characterization of sugar utilization in I. orientalis SD108. (A) Batch cultures using shake flasks profile of SD108 in SC medium containing $50 \mathrm{~g} / \mathrm{L}$ of glucose. (B) Batch cultures using shake flasks profile of SD108 in SC medium containing $50 \mathrm{~g} / \mathrm{L}$ of fructose.

rates were $68 \%, 65 \%, 12 \%$ and $25 \%$ higher than Classic Distiller's Turbo yeast under such conditions. It was noted that strain SD108 exhibits significantly improved tolerance over strain I. orientalis ATCC 24210 in the presence of $30 \mathrm{~g} / \mathrm{L}$ itaconic acid, $23 \mathrm{~g} / \mathrm{L}$ adipic acid and $20 \mathrm{~g} / \mathrm{L}$ acetic acid, where the maximum specific growth rates of SD108 were 16\%, 5\% and 10\% higher than those of I. orientalis ATCC 24210, respectively (Table 1).

\section{Genome sequencing and ploidy}

The above features emphasize the biotechnological potential of $I$. orientalis and reinforce a need for developing genetic manipulation tools for this strain. The availability of genome sequence of SD108 becomes important, which may serve as the molecular basis for designing genetic and metabolic engineering strategies. A draft genome sequence was established by whole-genome-shotgun and paired-end sequencing using the Genome Sequencer FLX + system and subsequent data assembly using the GS De Novo Assembler version 2.6 from 454 Life Sciences. There are 5,093 predicted genes, more than $85 \%$ of which have homologs in Pichia stipitis and S. cerevisiae. A schematic of predicted genes in I. orientalis SD108, related to carbohydrates utilization, glycolysis, pentose phosphate pathway, pyruvate metabolism, TCA cycle and glyoxylate shunt pathway, is shown in Additional file 1: Figure S3. In addition, relying on chromosomal DNA staining and flow cytometry [13], SD108 was determined as a diploid strain. More details about genome sequencing and ploidy determination are shown in supplementary materials.

\section{Generation of a uracil auxotroph I. orientalis SD108 strain}

We first sought to generate a uracil auxotroph strain as a recipient strain for future genetic manipulation with uracil auxotrophy as selection marker. The regions flanking the ura3 open reading frame were separated amplified and spliced via overlap extension PCR as a deletion fragment. After transforming $5 \mu \mathrm{g}$ of this deletion fragment into SD108, transformants were spread on SC+FOA plates. After incubation at $30^{\circ} \mathrm{C}$ for at least one week, twenty colonies appeared on the SC + FOA plate and each colony was restreaked on a SC-URA plate and a new SC + FOA plate in parallel. Eight of the twenty candidates could only grow on the SC + FOA plate (Additional file 1: Figure S5A) and PCR analysis of their isolated genomic DNAs confirmed the loss of both copies of ura3. Transforming these strains with a wild type ura 3 gene, yielding strain Io $\Delta$ ura $3+$ ura3, could complement the loss of ura3 function (Additional file 1: Figure S5B). As expected, only one locus was repaired, which was confirmed by PCR analysis (Additional file 1: Figure S5C).

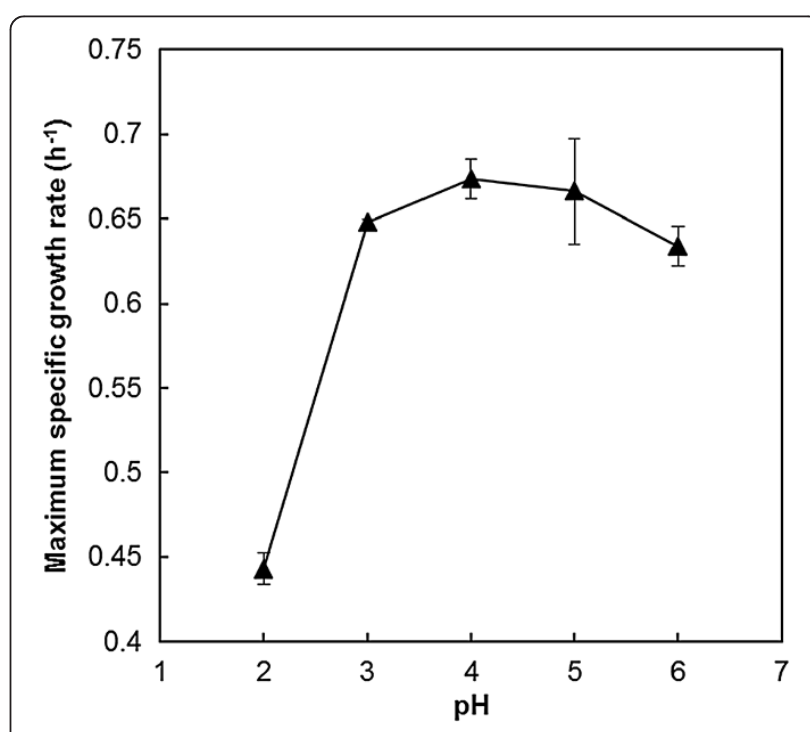

Figure 2 Maximum specific growth rates of $I$. orientalis SD108 in SC medium at different starting $\mathrm{pH}$ values. 


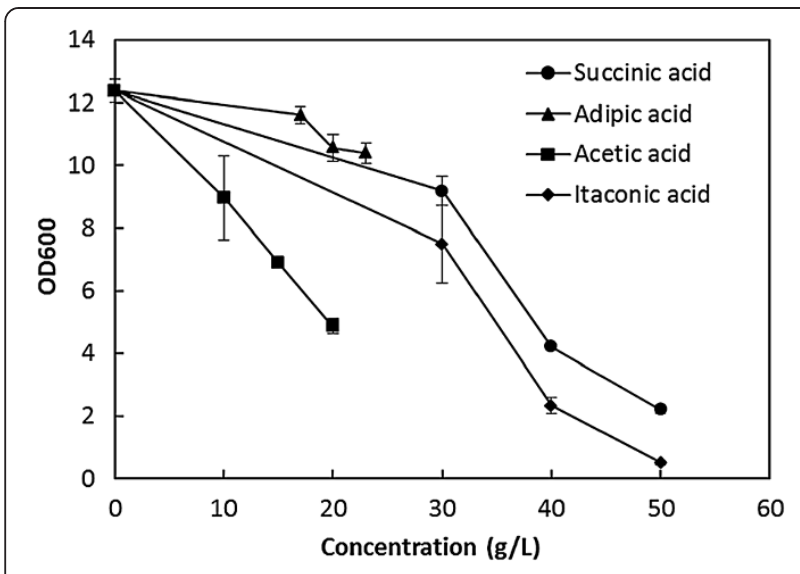

Figure 3 Cell growth of $I$. orientalis SD108 after $10 \mathrm{~h}$ in SC medium containing various organic acids. All the initial pH values were 5.6.
Metabolic engineering of succinic acid producing I. orientalis SD108 strain

As the next step to test whether SD108 could be a promising host for producing organic acids, we chose to work on the biosynthesis of succinic acid. The reductive TCA cycle, oxidative TCA cycle and glyoxylate shunt pathway are the three primary fermentation pathways for producing succinic acid (Figure 5), among which the reductive TCA cycle gives the highest theoretical yield on glucose (1.31 g/g) [14]. Based on the reductive TCA cycle, genes pyc, mdh, fumr and frd, encoding pyruvate carboxylase, malate dehydrogenase, fumarase and fumarate reductase, respectively, are the most important targets for applying metabolic engineering strategies to improve succinic acid production $[14,15]$. In addition, to avoid the potential issue with succinic acid being exported across the inner membranes (e.g., from mitochondria to cytoplasm),
A

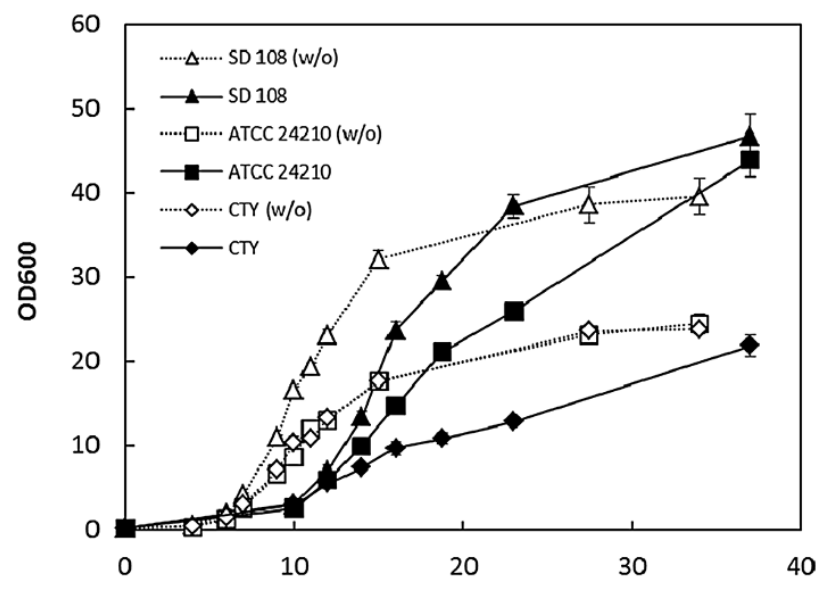

C

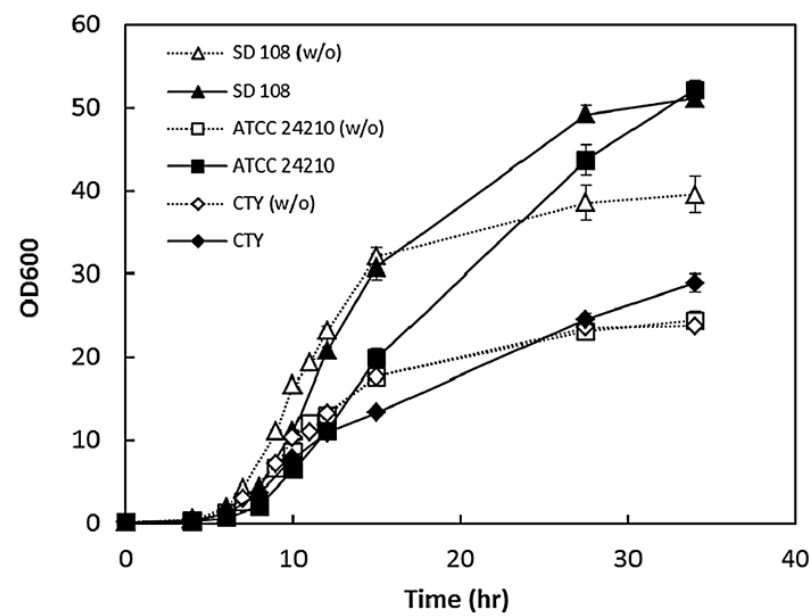

B
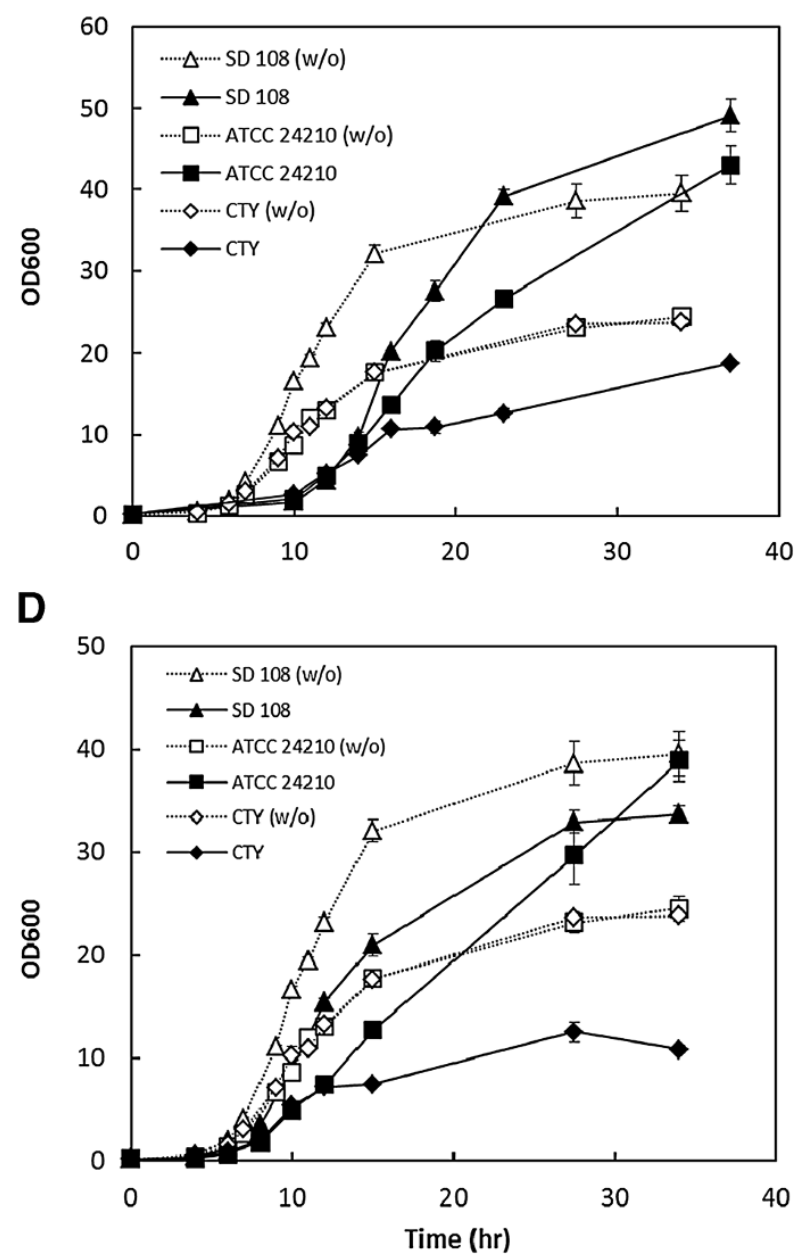

Figure 4 Cell growth of the strains in SC medium containing different organic acids. All the initial pH values were 5.6. SD 108, I. orientalis SD 108; ATCC24210, I. orientalis ATCC 24210; CTY, Classic Distiller's Turbo Yeast; w/o, without any organic acid added. (A) $30 \mathrm{~g} / \mathrm{L}$ of succinic acid; (B) $30 \mathrm{~g} / \mathrm{L}$ of itaconic acid; (C) $23 \mathrm{~g} / \mathrm{L}$ of adipic acid; (D) $20 \mathrm{~g} / \mathrm{L}$ of acetic acid. 
Table 1 Maximum specific growth rate of strains in SC medium containing $20 \mathrm{~g} / \mathrm{L}$ of acetic acid, $23 \mathrm{~g} / \mathrm{L}$ of adipic acid, $30 \mathrm{~g} / \mathrm{L}$ of itaconic acid and $30 \mathrm{~g} / \mathrm{L}$ of succinic acid, respectively

\begin{tabular}{|c|c|c|c|c|c|}
\hline \multirow[t]{2}{*}{ Strains } & \multicolumn{5}{|c|}{ Maximum specific growth rate $\left(\mathrm{h}^{-1}\right)$} \\
\hline & None & Succinic acid & Itaconic acid & Adipic acid & Acetic acid \\
\hline Classic Distiller's Turbo Yeast & $0.58 \pm 0.02$ & $0.22 \pm 0.01$ & $0.26 \pm 0.01$ & $0.52 \pm 0.01$ & $0.44 \pm 0.01$ \\
\hline I. orientalis ATCC 24210 & $0.65 \pm 0.02$ & $0.34 \pm 0.02$ & $0.37 \pm 0.03$ & $0.55 \pm 0.01$ & $0.50 \pm 0.03$ \\
\hline I. orientalis SD108 & $0.65 \pm 0.01^{\mathrm{a}}$ & $0.37 \pm 0.01^{\mathrm{a}}$ & $0.43 \pm 0.00^{\mathrm{a}, \mathrm{b}}$ & $0.58 \pm 0.01^{\mathrm{a}, \mathrm{b}}$ & $0.55 \pm 0.01^{\mathrm{a}, \mathrm{b}}$ \\
\hline
\end{tabular}

All the initial $\mathrm{pH}$ values were 5.6 .

${ }^{a}$ The maximum specific growth rate of strain 1 . orientalis SD108 was statistically significant over that of strain Classic Distiller's Turbo Yeast $(P<0.05)$ as determined by the Student t-test; ${ }^{\text {}}$ The maximum specific growth rate of strain I. orientalis SD108 was statistically significant over that of strain I. orientalis ATCC 24210 $(P<0.05)$ as determined by the Student t-test.

enzymes that are likely expressed in the cytoplasm became our first choice. According to the genome annotation, gene JL09_g1614 and JL09_g1983 are predicted to be the pyc and fumr genes, respectively. Three types of malate dehydrogenase - mitochondrial malate dehydrogenase, cytoplasmic malate dehydrogenase, and peroxisomal malate dehydrogenase - are found in yeast, which are named as MDH1, $\mathrm{MDH} 2$ and MDH3, respectively [16]. Genes JL09_g238, JL09_g1975 and JL09_g4199 are predicted as mdh. According to the amino acid identities with MDHs in S. cerevisiae S288c, all of the predicted MDHs share amino acid identities $(0.37 \sim 0.42)$ similar to MDH2 in S. cerevisiae S288c. Therefore, gene JLO9_g4199 was arbitrarily chosen as $m d h$. In addition, since none of the genes was identified as frd in the sequenced genome, we decided to test the previously reported codon-optimized FRD in S. cerevisiae [15] (Table 2). To ensure that all these enzymes would be co-expressed in the cytoplasm, potential signal peptides were removed (C-terminal PKL of MDH, N-terminal 15 amino acids of FUMR, and C-terminal SKI of FRD) according to the sequence information [15].

In order to obtain high transcription levels, the $p y c, m d h$, fumr and frd genes were individually cloned to downstream of strong promoters fbalp, teflap, pgklp and tdh3p, respectively. These promoters were chosen due to the relatively high transcription levels of the corresponding native genes under our cultivation conditions determined via realtime PCR analysis (Figure 6A). When SC-URA medium containing $50 \mathrm{~g} / \mathrm{L}$ glucose and $25.52 \mathrm{~g} / \mathrm{L}$ calcium carbonate was used as the shake flask culture broth, the final engineered strain Io $\Delta$ ura $3+$ SA consumed $49.72 \pm 0.01 \mathrm{~g} / \mathrm{L}$ glucose and produced $2.61 \pm 0.29 \mathrm{~g} / \mathrm{L}$ of succinic acid within $24 \mathrm{~h}$, while strain Io $\Delta$ ura $3+$ ura 3 consumed $49.71 \pm 0.01$ $\mathrm{g} / \mathrm{L}$ glucose and only produced $0.37 \pm 0.01 \mathrm{~g} / \mathrm{L}$ of succinic acid under the same condition. The enhancement of the transcriptional levels of $p y c, m d h$, fumr and frd was further confirmed in strain Io $\Delta$ ura3 + SA (Figure 6B).

To further compare the shake flask culture characteristics, Io $\Delta$ ura $3+$ SA strains were tested in SC-URA medium containing $100 \mathrm{~g} / \mathrm{L}$ glucose and $25.52 \mathrm{~g} / \mathrm{L}$ calcium carbonate. No significant differences were found in glucose consumption, growth and ethanol production between strain Io $\Delta$ ura $3+S A$ and strain Io $\Delta$ ura $3+$ ura 3 over the entire shake flask culture course (Figure 7A, B and D). Strain Io $\Delta$ ura $3+$ SA was able to consume all glucose and produce $11.63 \pm 1.38 \mathrm{~g} / \mathrm{L}$ succinic acid at $110 \mathrm{~h}$, whereas strain

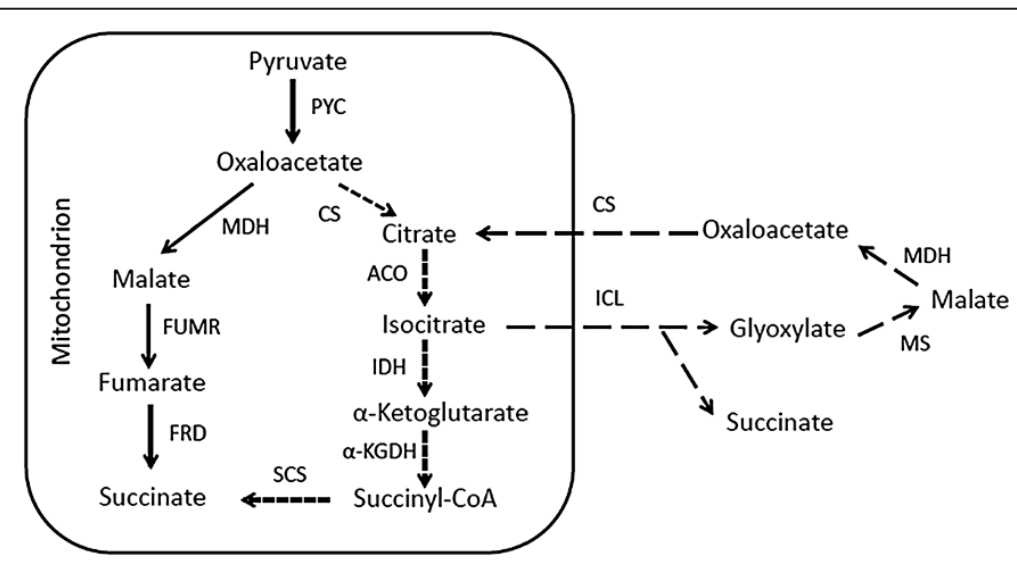

Figure 5 Three fermentation pathways for succinate production. The reductive TCA, oxidative TCA and glyoxylate shunt pathway were shown by solid, short dashed and long dashed arrows respectively. PYC, pyruvate carboxylase; MDH, malate dehydrogenase; FUMR, fumarase; FRD, fumarate reductase; CS, citrate synthase; ACO, aconitase; IDH, isocitrate dehydrogenase; a-KGDH, a-ketoglutarate; SCS, succinyl coenzyme A synthetase; ICL, isocitrate lyase; MS, malate synthase. 
Table 2 Strains and plasmids used in this study

\begin{tabular}{|c|c|c|}
\hline $\begin{array}{l}\text { Strains or } \\
\text { plasmids }\end{array}$ & Characteristics & $\begin{array}{l}\text { Reference } \\
\text { or source }\end{array}$ \\
\hline \multicolumn{3}{|l|}{ Strains } \\
\hline \multicolumn{3}{|l|}{ I. orientalis } \\
\hline ATCC 24210 & Wild type & NRRL \\
\hline SD108 & Wild type & This study \\
\hline lo $\Delta$ ura3 & SD108/ura3A & This study \\
\hline $\begin{array}{l}\text { lo } \Delta \text { ura3 }+ \\
\text { ura3 }\end{array}$ & lo $\Delta$ ura3/ura3 $\Delta:$ :ura3 & This study \\
\hline $\begin{array}{l}\text { lo } \Delta \text { ura3 + } \\
\text { SA }\end{array}$ & $\begin{array}{l}\text { lo } \Delta \text { ura3/ura3 } \Delta: \text { :ura3-succinic } \\
\text { acid biosynthetic pathway }\end{array}$ & This study \\
\hline \multicolumn{3}{|l|}{ S. cerevisiae } \\
\hline BY4741 & MATa his $3 \Delta 0$ leu $2 \Delta 0$ met $15 \Delta 0$ ura $3 \Delta 0$ & Reference [17] \\
\hline PRT238 & Wild type & $\begin{array}{l}\text { Offered by Dr. } \\
\text { Peter Orlean }\end{array}$ \\
\hline $\begin{array}{l}\text { Classic } \\
\text { Distiller's } \\
\text { Turbo Yeast }\end{array}$ & Wild type & Reference [18] \\
\hline \multicolumn{3}{|l|}{ E. coli } \\
\hline $\mathrm{DH} 5 \mathrm{a}$ & General cloning host & Takara \\
\hline BW25141 & Cloning host & $\begin{array}{l}\text { Provided by } \\
\text { Professor } \\
\text { William Metcalf }\end{array}$ \\
\hline \multicolumn{3}{|l|}{ Plasmids } \\
\hline pPK2 & $\begin{array}{l}\text { ColE1 ORI, Ampr', C. parapsilosis ARS7 ORI, } \\
\text { CpURA3 }\end{array}$ & Reference [19] \\
\hline pPICZaA & $\begin{array}{l}\text { With gene ble, encoding the zeocin } \\
\text { resistance gene, under the control } \\
\text { of Saccharomyces cerevisiae TEF1 } \\
\text { promoter. }\end{array}$ & $\begin{array}{l}\text { Life } \\
\text { Technologies }\end{array}$ \\
\hline pPK2-zeocin & $\begin{array}{l}\text { Derived from pPK2, with zeocin } \\
\text { expression cassette inserted at the } \\
\text { region of ura3 expression cassette }\end{array}$ & This study \\
\hline pXZ1 & $\begin{array}{l}\text { Derived from pPK2, with C. parapsilosis } \\
\text { ARS7 ORI deleted. }\end{array}$ & This study \\
\hline pXZ2 & $\begin{array}{l}\text { Plasmid which can be maintained } \\
\text { in SD108 }\end{array}$ & This study \\
\hline pFRD & $\begin{array}{l}\text { With codon optimized frd gene for } S \text {. } \\
\text { cerevisiae (Genbank accession number } \\
\text { AAN40014) }\end{array}$ & $\begin{array}{l}\text { Synthesized by } \\
\text { DNA } 2.0\end{array}$ \\
\hline pRS415 & Yeast centromere with LEU2 marker & NEB \\
\hline pRS415-A & $\begin{array}{l}\text { Derived from pRS415, with ura3 } \\
\text { expression cassette added }\end{array}$ & This study \\
\hline pRS415-B & $\begin{array}{l}\text { Derived from pRS415, with pyc } \\
\text { expression cassette added }\end{array}$ & This study \\
\hline pRS415-C & $\begin{array}{l}\text { Derived from pRS415, with mdh } \\
\text { and fumr expression cassette added }\end{array}$ & This study \\
\hline pRS415-D & $\begin{array}{l}\text { Derived from pRS415, with frd expression } \\
\text { cassette added }\end{array}$ & This study \\
\hline pRS415-E & $\begin{array}{l}\text { Derived from pRS415-A, with pyc, } \\
\text { mdh, fumr and frd expression } \\
\text { cassettes added }\end{array}$ & This study \\
\hline
\end{tabular}

Io $\Delta$ ura $3+$ ura3 consumed $99.29 \pm 0.08 \mathrm{~g} / \mathrm{L}$ glucose and yielded $1.43 \pm 0.04 \mathrm{~g} / \mathrm{L}$ succinic acid during the same period (Figure 7B). Because of the neutralization by calcium carbonate, the final $\mathrm{pH}$ of strain Io $\Delta$ ura $3+\mathrm{SA}$ was only 1.78 units lower than that of strain Io $\Delta$ ura3 + ura3 $(5.08 \pm 0.12$ vs. $6.86 \pm 0.74)$. Notably, the glycerol produced by strain Io $\Delta$ ura $3+$ SA was much lower than strain Io $\Delta$ ura $3+$ ura3 (Figure 7C), which may be attributed to the amount of NADH needed by the reductive TCA cycle $[14,15,20]$. In addition, the acetic acid produced by strain Io $\Delta$ ura $3+$ SA was also lower than that of strain Io $\Delta$ ura $3+$ ura 3 (Figure 7C). Although formation of acetic acid may be due to the regeneration of reducing equivalents, the substrate oxaloacetate required by the reductive TCA cycle may become a driving force for directing pyruvate into oxaloacetate instead of acetic acid [21]. As a result, the succinic acid titer, yield on glucose, and productivity of strain Io $\Delta$ ura $3+$ SA $(11.63 \mathrm{~g} / \mathrm{L}, 0.12 \mathrm{~g} / \mathrm{g}$ and $0.11 \mathrm{~g} / \mathrm{L}$. h) were much higher than those of strain Io $\Delta$ ura3 + ura3 $(1.43 \mathrm{~g} / \mathrm{L}, 0.01 \mathrm{~g} / \mathrm{g}$ and $0.01 \mathrm{~g} / \mathrm{L} \cdot \mathrm{h})$.

\section{Discussion}

Product toxicity is a lingering problem in developing economical fermentative processes for production of organic acids despite decades of research. In addition, economically viable biorefinery operations require the use of cheap substrates such as lignocellulosic hydrolysates. This necessitates the use of strains with two properties: first, the ability to utilize various biomass sugars, and second, the ability to tolerate inhibitors contained in lignocellulosic hydrolysates. Although SD108 cannot intrinsically utilize many sugars released from lignocellulosic hydrolysates, it should be feasible to introduce the sugar utilization pathways from related species (e.g. Pichia kudriavzevii M12 [22]) into this strain, similar to strategies which have been successfully applied in S. cerevisiae [23-25]. Moreover, various by-products, mainly organic acids, are inevitably generated during hydrolysis and exert negative effects on the host [26]. In these scenarios, platform organisms which tolerate multiple organic acids have an obvious advantage as they can utilize hydrolysates more robustly. The high tolerance of I. orientalis SD108 towards multiple important organic acids makes it a highly attractive platform host for producing this group of compounds. In addition, the doubling time of SD108 was 11\% shorter than the fast growing yeast, Classic Distiller's Turbo Yeast (1.06 h vs. 1.19 h) (Table 1 and Figure 4). This means that more cells of SD108 are available during the same time period, and thus the high productivity desired in industrial processes may be achieved more easily.

For such a potential platform organism, the availability of its genome sequence is essential. It will offer further insights into its properties, and more importantly, facilitate the genetic and metabolic engineering studies. The 


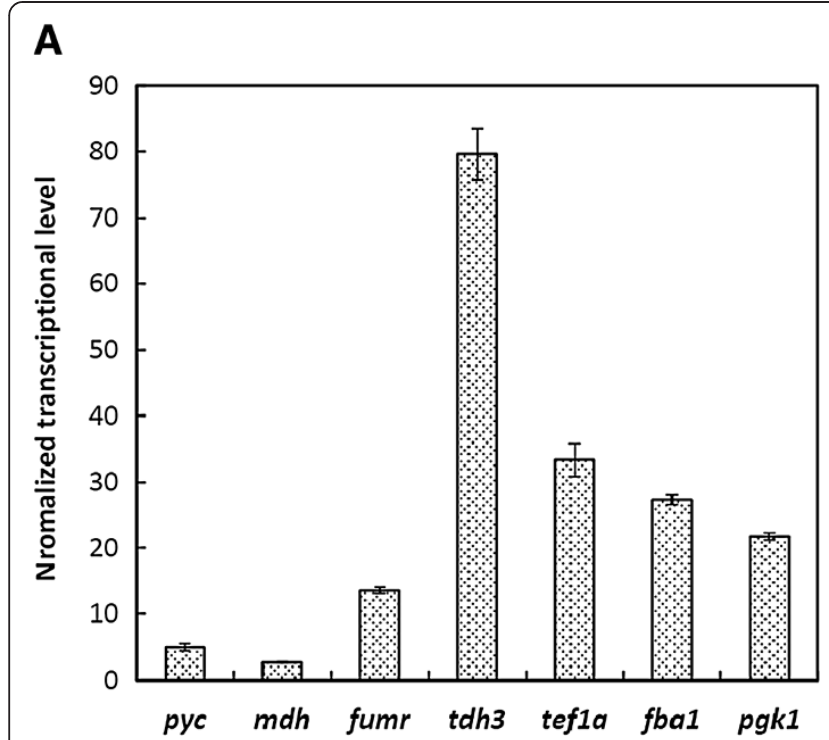

B

Figure 6 Transcritional profiles of the succinic acid pathway, gene alg9 was used as the internal control. (A) Transcriptional levels of the succinic acid pathway at $24 \mathrm{~h}$ in strain lo $\Delta$ ura3 + ura3. Shake flask culture experiments were carried out in the SC-URA medium containing $50 \mathrm{~g} / \mathrm{L}$ glucose; (B) Transcriptional levels of genes pyc, mdh, fumr and frd at $48 \mathrm{~h}$ in the lo $\Delta$ ura3 + ura3 and lo $\Delta \mathrm{ura} 3+\mathrm{SA}$ strains. Shake flask culture experiments were carried out in the SC-URA medium containing $50 \mathrm{~g} / \mathrm{L}$ glucose and $25.52 \mathrm{~g} / \mathrm{L}$ calcium carbonate.

molecular mechanisms underlying the ability of I. orientalis to resist the lethal effects of a spectrum of organic acids have not been identified. Normally, acid stress will induce complex transcriptional responses and intricate processes that relate to a set of genes. Hence genomewide analysis of the transcriptome and proteome are usually needed to identify the genes involved in stress response $[27,28]$. Known tolerance mechanisms used by $S$. cerevisiae and E. coli to cope with acidic environments include, but are not limited to, inducing expression of stress genes, changing membrane composition, transporting protons out of the cell, and consuming protons via decarboxylation reactions [27,29-32]. By comparison of previously identified determinants of acid tolerance, candidate genes related to acid tolerance in I. orientalis SD108 are summarized in Additional file 1: Table S5. Our draft genome sequence offers a basis for designing further functional genomics studies to investigate the mechanisms underlying acid tolerance.

Succinic acid production is a specific example of exploiting genome information to rewire metabolic pathways. By integration of endogenous genes $p y c, m d h$, fumr and an exogenous gene frd driven by endogenous strong promoters, the resultant strain exhibited significant improvement of the titer, yield and productivity (Figure 7). The reductive TCA cycle is the most interesting pathway for succinic acid production. While it provides the highest succinic acid yield on glucose as compared with the other two pathways, the net deficit in reducing power (NADH) poses a challenge for metabolic engineering [14]. Strategies to address the redox imbalance

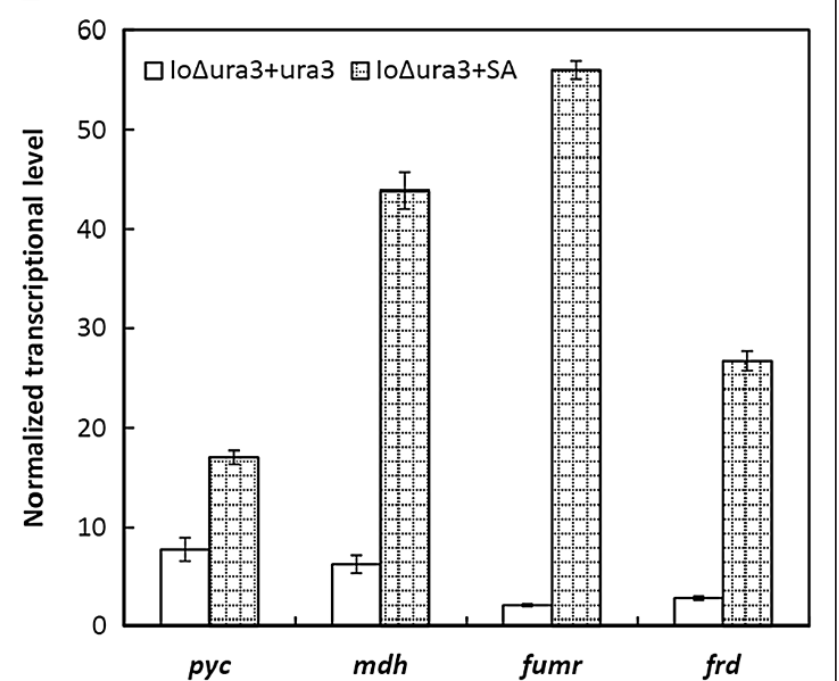

include either combining the oxidative TCA and/or glyoxylate shunt pathways with the reductive TCA cycle, supplying NADH and direct carbon flux into succinic acid, or introducing other pathways for NADH supply (e.g., glucose-6-phosphate dehydrogenase) [33,34]. In addition, blocking byproduct production (e.g., glycerol, ethanol and acetate) and deletion of the reverse reactions of the reductive TCA cycle (e.g., from succinate to fumarate, which is catalyzed by succinate dehydrogenase) should also be considered in future plans.

In addition to chromosomal integration, an episomal plasmid based expression system is desirable in a potential platform organism. Neither $2 \mu$ nor CEN ARS sequences, which are commonly used as the origin of replication in S. cerevisiae, could be maintained in SD108. We were able to successfully identify a functional ARS from the digested genomic DNA of SD108 (Additional file 1: Figure S6). The plasmid containing this 91 bp sequence could express zeocin resistance marker and can be maintained throughout the cultivation process, providing another viable option to express the target pathway in this host. We are currently determining the copy number of such an ARS and testing the succinic acid production if the associated genes are expressed on an episomal plasmid. In addition, SD108 is diploid, which makes gene deletion inconvenient. The plasmid-based expression in SD108 should facilitate the deployment of recently developed powerful genome editing tools (e.g., TALEN and CRISPR) [35-39], which may delete multiple copies of one gene or different genes simultaneously. 

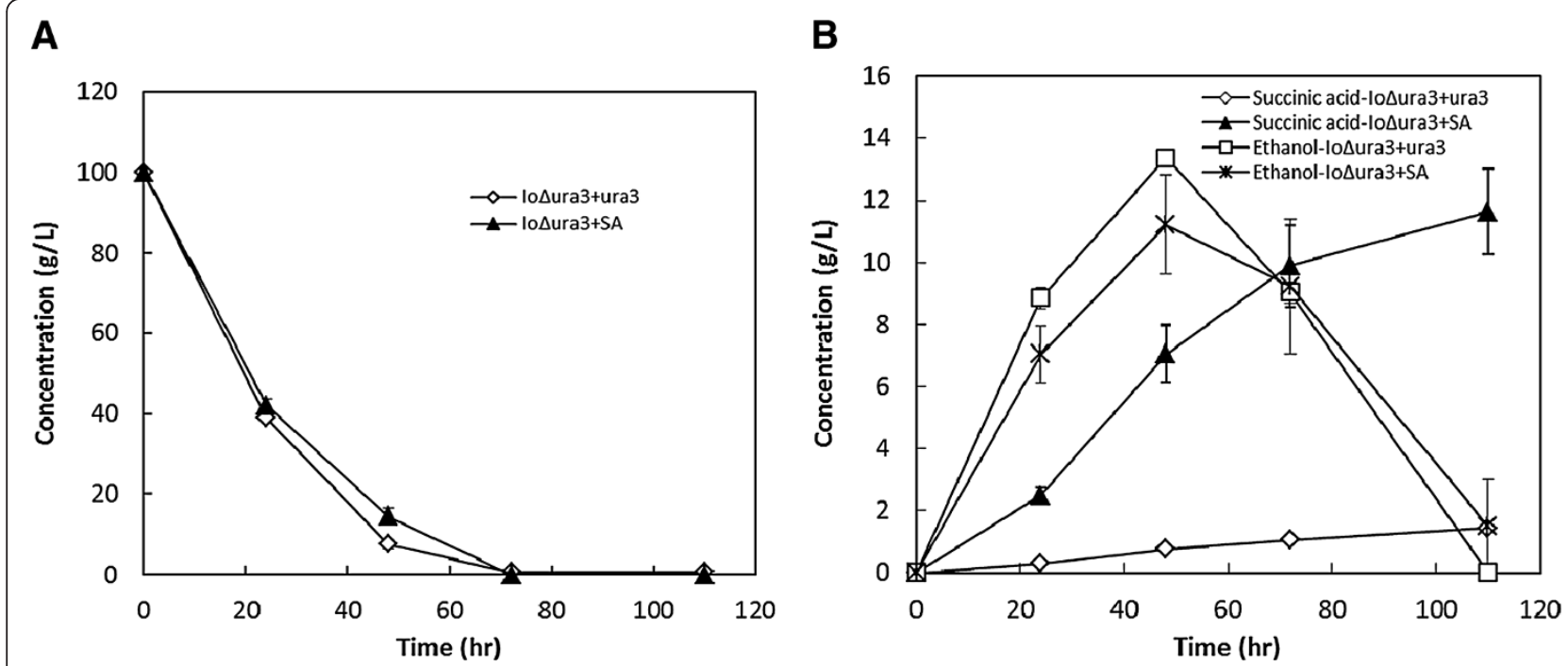

C

D
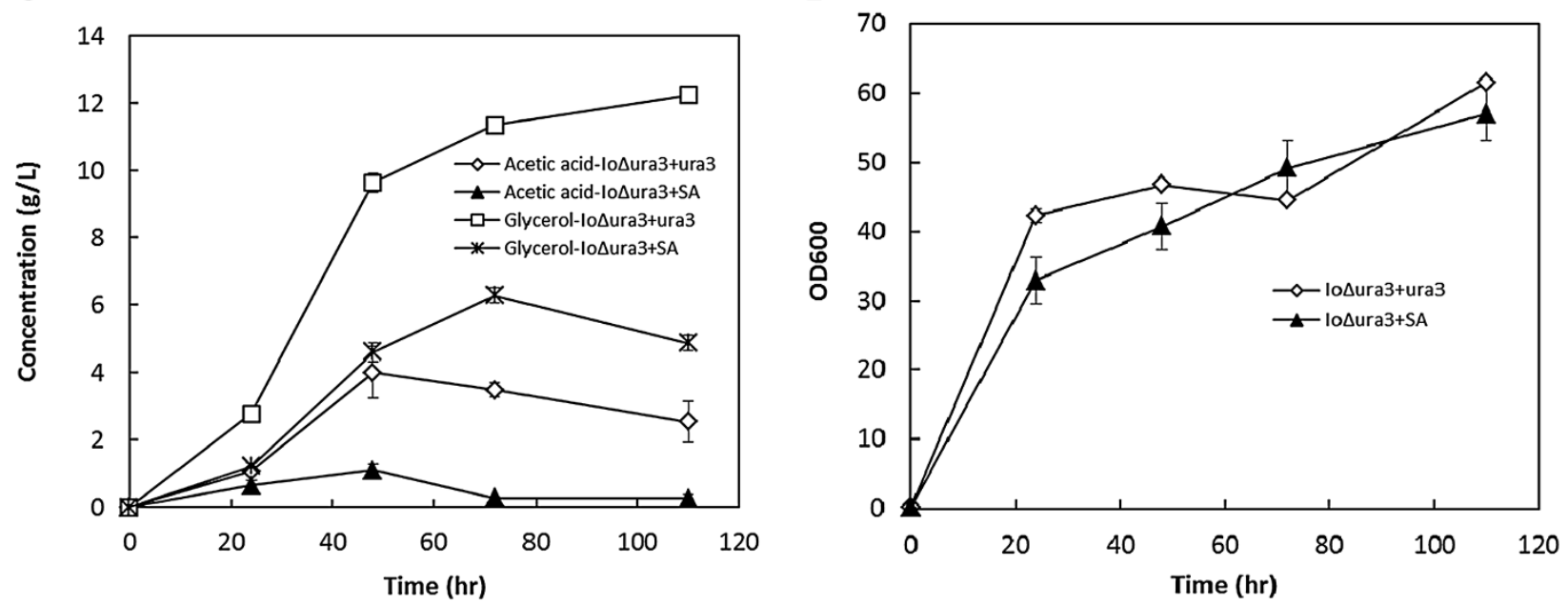

Figure 7 Growth and metabolite profiles in batch culture using shake flasks of strain lo $\Delta$ ura $3+$ ura 3 and strain lo $\Delta$ ura $3+S A$ in the SC-URA medium containing $100 \mathrm{~g} / \mathrm{L}$ glucose. (A) Sugar consumption; (B) Succinic acid and ethanol concentration; (C) Acetic acid and glycerol concentration; (D) Cell growth.

\section{Conclusions}

The organic acid biorefinery industry demands a better "microbial factory" that exhibits an excellent tolerance to moderately low $\mathrm{pH}$ and high product titer conditions, and can grow and produce the target organic acid at high rates. I. orientalis SD108 indeed demonstrates an exceptional tolerance towards multiple industrially important organic acids. Our biochemical and genetic characterization provides a resource to identify novel candidate genes coding for proteins involved in acid tolerance and offers a basis to design future strategies to evaluate its metabolic capabilities and biotechnologically important features. Based on the genome information, genetic tools for SD108 have been developed and metabolic engineering strategies have successfully been applied for increasing succinic acid production, which further makes this strain more attractive.

\section{Materials and methods}

\section{Strains and growth media}

The strains and plasmids used in this study are listed in Table 2. Cells were grown in liquid SC [18], SC-URA or SC-LEU medium supplemented with various sugars as the carbon source or on solid YPAD medium (1\% yeast extract, $2 \%$ peptone, $0.01 \%$ adenine hemisulfate, $2 \%$ glucose and $2 \%$ agar) unless otherwise noted. The initial $\mathrm{pH}$ value of SC culture was adjusted to 5.6 using $12 \mathrm{M} \mathrm{NaOH}$, and was not controlled during shake flask culture. For isolation and identification of SD108, see Additional file 1: Supplementary data for details. 


\section{Tolerance assay}

For calculating maximum specific growth rates of $I$. orientalis SD108 at different starting $\mathrm{pH}$ values, stationary-phase cells grown in SC medium [18] were transferred into $5 \mathrm{~mL}$ of SC medium containing $50 \mathrm{~g} / \mathrm{L}$ glucose in a $15 \mathrm{~mL}$ round-bottom Falcon tube $\left(30^{\circ} \mathrm{C}, 250 \mathrm{rpm}\right)$. The initial $\mathrm{pH}$ values were adjusted to $0,1,2,3,4,5$ or 6 by using $12 \mathrm{M} \mathrm{HCl}$ or $12 \mathrm{M} \mathrm{NaOH}$, citric acid-sodium citrate buffer solutions were used to maintain the $\mathrm{pH}$ (http://www.sigmaaldrich.com/life-science/core-bioreagents/ biological-buffers/learning-center/buffer-reference-center. html) (Additional file 1: Figure S2). To determine cell growth of $I$. orientalis SD108 in SC medium containing various organic acids, stationary-phase cells grown in SC medium were transferred into $5 \mathrm{~mL}$ of SC medium containing $50 \mathrm{~g} / \mathrm{L}$ glucose and various concentrations of organic acids in a $15 \mathrm{~mL}$ round-bottom Falcon tube $\left(30^{\circ} \mathrm{C}\right.$, $250 \mathrm{rpm}$ ). Cell densities after 10 hours of growth were measured. For the organic acid tolerance assay, stationaryphase cells grown in SC medium containing $50 \mathrm{~g} / \mathrm{L}$ glucose were transferred into $20 \mathrm{~mL}$ of fresh $\mathrm{SC}$ medium containing $50 \mathrm{~g} / \mathrm{L}$ glucose and various organic acids at appropriate concentrations in $125 \mathrm{~mL}$ non-baffled shake flasks. Cells were grown under oxygen-limited conditions as described previously $\left(30^{\circ} \mathrm{C}, 100 \mathrm{rpm}\right)$ [18]. The initial $\mathrm{OD}_{600}$ for various tolerance assays were 0.2 . The initial $\mathrm{pH}$ values were adjusted to 5.6 using $12 \mathrm{M} \mathrm{NaOH}$ except as described elsewhere.

\section{DNA transformation of SD108 and its derived strains}

DNA transformation of SD108 and its derived strains was carried out using the method developed by Gietz and Schiestl [40]. See Additional file 1: Supplementary data for details.

\section{Generation of a uracil auxotroph SD108 strain}

Genomic DNA from I. orientalis SD108 was isolated with the Wizard Genomic DNA Purification Kit (Promega, Madison, WI). An upstream homology arm of 543 bp and a downstream homology arm of 279 bp were PCRamplified separately from the genomic DNA using primers Ura-p-up/Ura-p-dn and Ura-t-up/Ura-t-dn, respectively (Additional file 1: Table S1). These arms were spliced into a ura3 deletion fragment via overlap extension PCR [41]. A total of $5 \mu \mathrm{g}$ of the ura3 deletion fragment was used to delete both copies of ura3 simultaneously. DNA transformation was carried out with the time for heat shock being 90 min. Transformants were spread on SC+FOA plates and incubated at $30^{\circ} \mathrm{C}$ for approximately 10 days. Transformation protocol was further optimized using the uracil auxotroph SD108 strain as a starting strain. See Additional file 1: Supplementary data for details.

\section{Assembly of the reductive TCA pathway for succinic acid production}

Pathway construction was carried out using the DNA assembler method [42]. See Additional file 1: Supplementary data for details.

\section{RNA preparation and quantitative PCR analysis}

Samples for qPCR were collected from $20 \mathrm{~mL}$ of SC-URA medium containing $50 \mathrm{~g} / \mathrm{L}$ glucose or $50 \mathrm{~g} / \mathrm{L}$ glucose plus $25.52 \mathrm{~g} / \mathrm{L}$ calcium carbonate. RNA preparation, generation of cDNA and real-time PCR analysis were performed as described previously [43]. The alg9 gene was used as an internal control, commonly used as the internal control for transcriptional analysis in S. cerevisiae [44]. The qPCR primers are listed in Additional file 1: Table S1.

\section{Shake flask cultures}

Batch cultures using shake flasks were carried out as follows: a single colony grown on SC-URA plate was inoculated into $3 \mathrm{~mL}$ of SC-URA medium containing $2 \%$ glucose in a $15 \mathrm{~mL}$ round-bottom Falcon tube and grown until saturation $\left(30^{\circ} \mathrm{C}, 250 \mathrm{rpm}\right)$. About $100 \mu \mathrm{L}$ of the stationaryphase cells were transferred into $20 \mathrm{~mL}$ of fresh SC-URA media containing $25.52 \mathrm{~g} / \mathrm{L}$ calcium carbonate and different concentrations of glucose in $125 \mathrm{~mL}$ non-baffled shake flasks. Cells were grown under oxygen-limited conditions $\left(30^{\circ} \mathrm{C}, 100 \mathrm{rpm}\right)$. The initial $\mathrm{OD}_{600}$ was 0.2 .

\section{HPLC analysis}

The samples were centrifuged and the supernatants were diluted 0 to 10 times before HPLC analysis. An HPLC system equipped with a refractive index detector (Shimadzu Scientific Instruments, Columbia, MD) was used to analyze the concentrations of glucose, xylose, arabinose, cellobiose, galactose, sucrose, fructose, ethanol, acetic acid, glycerol and succinic acid in the broth. To separate all the metabolites mentioned above, an HPX-87H column (BioRad, Hercules, CA) was used as described previously [18]. The HPLC chromatogram was analyzed using the LCsolution software (Shimadzu Scientific Instruments, Columbia, MD).

\section{Additional file}

\section{Additional file 1: Supplementary Data.}

\section{Abbreviations}

DOE: Department of energy; FOA: 5-Fluoroorotic acid; FRD: Fumarate reductase; FUMR: Fumarase; $M D H$ : Malate dehydrogenase; PYC: Pyruvate carboxylase; SC: Synthetic complete.

Competing interests

The authors declare that they have no competing interests. 


\section{Authors' contributions}

The characterization, tolerance assay and metabolic engineering of succinic acid producing 1 . orientalis SD108 strain were performed by HX and ZS. Genome size and ploidity were estimated by YJ. Genome was sequenced and analyzed by HX, ZS, YJ, High-Performance Biological Computing and the DNA sequencing facility at University of Illinois. Strain SD108 was isolated, identified and initial low pH and organic acid tolerance was done by SD. All authors contributed to the writing and have approved the final manuscript.

\section{Authors' information}

Dr. Zengyi Shao: Assistant professor, Department of Chemical and Biomolecular Engineering, 4140 Biorenewables Research Laboratory, lowa State University, Ames, IA 50011; Dr. Yu Jiang: Associate Professor, Fenglin Road \#300, Institute of Plant Physiology and Ecology, Shanghai Institutes for Biological Sciences, Chinese Academy of Science. Dr. Sudhanshu Dole: Senior scientist, Molecular Biology Department, Myriant Corporation, 66 Cummings Park, Woburn, MA 01801

\section{Acknowledgements}

The project was funded by Myriant Corporation. We thank the High-Performance Biological Computing and DNA sequencing facility at the University of Illinois for genome sequencing, annotation and release, ARS Culture Collection (NRRL) for offering strain I. orientalis ATCC 24210, Dr. Peter Orlean (Department of Microbiology, University of Illinois at Urbana-Champaign, Urbana, USA) for offering strain S. cerevisiae PRT238, Dr. William Metcalf (Department of Molecular and Cellular Biology, University of Illinois at Urbana-Champaign, Urbana, USA) for offering strain E.coli BW25141, Dr. Jozef Nosek (Department of Biochemistry and Genetics, Comenius University, Bratislava, Slovak Republic) for offering plasmid pPK2, Dr. Giek Far Chan (School of Applied Science, Temasek Polytechnic, Singapore) for providing genome information of Pichia kudriavzevii M12, Mr. Ryan E. Cobb, Mr. Jing Liang (Department of Chemical and Biomolecular Engineering, University of Illinois at Urbana-Champaign, Urbana, USA) and Dr. Zihe Liu (Metabolic Engineering Research Laboratory, Institute of Chemical and Engineering Science, Agency for Science, Technology and Research, Singapore) for helpful suggestions and thoughtful discussions.

\section{Author details}

${ }^{1}$ Department of Chemical and Biomolecular Engineering, University of Illinois at Urbana-Champaign, Urbana, IL 61801, USA. ${ }^{2}$ Key Laboratory of Synthetic Biology, Institute of Plant Physiology and Ecology, Shanghai Institutes for Biological Sciences, Chinese Academy of Sciences, Shanghai 200032, China. ${ }^{3}$ Molecular Biology Department, Myriant Corporation, 66 Cummings Park, Woburn, MA 01801, England. ${ }^{4}$ Departments of Chemistry, Biochemistry, and Bioengineering, Institute for Genomic Biology, University of Illinois at Urbana-Champaign, Urbana,

IL 61801, USA.

Received: 27 May 2014 Accepted: 10 August 2014

Published: 27 August 2014

\section{References}

1. Werpy T, Petersen G: Top Value Added Chemicals from Biomass, vol. I: Results of Screening for Potential Candidates from Sugars and Synthesis Gas. In 2004 [http://www1.eere.energy.gov/bioenergy/pdfs/35523.pdf]

2. Song H, Lee SY: Production of succinic acid by bacterial fermentation. Enzyme Microb Technol 2006, 39:352-361.

3. Beardslee T, Picataggio S: Biological Methods for Preparing Adipic Acid. US; 2012. patent 8241879 B2

4. Tanaka K, Ishii Y, Ogawa J, Shima J: Enhancement of acetic acid tolerance in Saccharomyces cerevisiae by overexpression of the HAA1 Gene, encoding a transcriptional activator. Appl Environ Microbiol 2012, 78:8161-8163

5. Abbott DA, Zelle RM, Pronk JT, Van Maris AJ: Metabolic engineering of Saccharomyces cerevisiae for production of carboxylic acids: current status and challenges. FEMS Yeast Res 2009, 9:1123-1136.

6. Hisamatsu M, Furubayashi T, Karita S, Mishima T, Isono N: Isolation and identification of a novel yeast fermenting ethanol under acidic conditions. J App/ Glycosci 2006, 53:111-113.

7. Thalagala TATP, Kodama S, Mishima T, Isono N, Furujyo A, Kawasaki Y, Hisamatsu M: Study on ethanol fermentation using D-glucose rich fractions obtained from lignocelluloses by a two-step extraction with sulfuric acid and Issatchenkia orientalis MF 121. J Appl Glycosci 2009, 56:7-11.

8. Suominen P, Aristidou A, Penttila M, Ilmen M, Ruohonen L, Koivuranta K, Roberg-Perez K: Genetically Modified Yeast of the Species Issatchenkia orientalis and Closely Relates Species, and Fermentation Processes using Same. In 2012. patent 8,097,448.

9. Balat $\mathrm{M}$, Balat $\mathrm{H}, \mathrm{Oz} \mathrm{C}$ : Progress in bioethanol processing. Prog Energy Combust Sci 2008, 34:551-573.

10. Fitzpatrick $M$, Champagne $P$, Cunningham MF, Whitney RA: A biorefinery processing perspective: treatment of lignocellulosic materials for the production of value-added products. Bioresour Technol 2010, 101:8915-8922.

11. Kumar R, Singh S, Singh OV: Bioconversion of lignocellulosic biomass: biochemical and molecular perspectives. J Ind Microbiol Biotechnol 2008, 35:377-391.

12. Van Maris AJA, Abbott DA, Bellissimi E, van den Brink J, Kuyper M, Luttik MAH, Wisselink HW, Scheffers WA, Van Dijken JP, Pronk JT: Alcoholic fermentation of carbon sources in biomass hydrolysates by Saccharomyces cerevisiae: current status. Anton Leeuw Int J G 2006, 90:391-418

13. Almeida AJ, Matute DR, Carmona JA, Martins M, Torres I, McEwen JG, Restrepo A, Leao C, Ludovico P, Rodrigues F: Genome size and ploidy of Paracoccidioides brasiliensis reveals a haploid DNA content: flow cytometry and GP43 sequence analysis. Fungal Genet Biol 2007, 44:25-31.

14. Finley KR, Huryta JM, Mastel BM, Mcmullin TW, Poynter GM, Rush BJ, Watts KT, Fosmer AM, Mcintosh JRVL, Brady KM: Compositions and Methods for Succinate Production. In 2012. patent WO2012103261 A2.

15. Verwaal R, Wu L, Damveld AR, Sagt JMC: Succinic Acid Production in a Eukaryotic Cell. US; 2012. patent 20120165569 A1

16. Gibson N, Mcalister-Henn L: Physical and genetic interactions of cytosolic malate dehydrogenase with other gluconeogenic enzymes. $J$ Biol Chem 2003, 278:25628-25636.

17. Radonjic M, Andrau JC, Lijnzaad P, Kemmeren P, Kockelkorn T, Van Leenen D, Van Berkum NL, Holstege FC: Genome-wide analyses reveal RNA polymerase II located upstream of genes poised for rapid response upon S. cerevisiae stationary phase exit. Mol Cell 2005, 18:171-183.

18. Du J, Yuan Y, Si T, Lian J, Zhao H: Customized optimization of metabolic pathways by combinatorial transcriptional engineering. Nucleic Acids Res 2012, 40:e142

19. Kosa P, Gavenclakova B, Nosek J: Development of a set of plasmid vectors for genetic manipulations of the pathogenic yeast Candida parapsilosis. Gene 2007, 396:338-345.

20. Geertman JMA, Van Dijken JP, Pronk JT: Engineering NADH metabolism in Saccharomyces cerevisiae: formate as an electron donor for glycerol production by anaerobic, glucose-limited chemostat cultures. FEMS Yeast Res 2006, 6:1193-1203.

21. Thakker C, Zhu J, San KY, Bennett G: Heterologous pyc gene expression under various natural and engineered promoters in Escherichia coli for improved succinate production. J Biotechnol 2011, 155:236-243.

22. Chan GF, Gan HM, Ling HL, Rashid NA: Genome sequence of Pichia kudriavzevii M12, a potential producer of bioethanol and phytase. Eukaryot Cell 2012, 11:1300-1301.

23. Becker J, Boles E: A modified Saccharomyces cerevisiae strain that consumes L-arabinose and produces ethanol. Appl Environ Microbiol 2003, 69:4144-4150.

24. Hahn-Hagerdal B, Wahlbom CF, Gardonyi M, Van Zyl WH, Cordero Otero RR, Jonsson LJ: Metabolic engineering of Saccharomyces cerevisiae for xylose utilization. Adv Biochem Eng Biotechnol 2001, 73:53-84.

25. Kotter P, Ciriacy M: Xylose fermentation by Saccharomyces-cerevisiae. Appl Microbiol Biotechnol 1993, 38:776-783.

26. Palmqvist E, Hahn-Hagerdal B: Fermentation of lignocellulosic hydrolysates. II: inhibitors and mechanisms of inhibition. Bioresour Technol 2000, 74:25-33.

27. King T, Lucchini S, Hinton JC, Gobius K: Transcriptomic analysis of Escherichia coli 0157:H7 and K-12 cultures exposed to inorganic and organic acids in stationary phase reveals acidulant- and strain-specific acid tolerance responses. Appl Environ Microbiol 2010, 76:6514-6528.

28. Guerreiro JF, Mira NP, Sa-Correia I: Adaptive response to acetic acid in the highly resistant yeast species Zygosaccharomyces bailii revealed by quantitative proteomics. Proteomics 2012, 12:2303-2318.

29. Kawahata M, Masaki K, Fujii T, lefuji H: Yeast genes involved in response to lactic acid and acetic acid: acidic conditions caused by the organic acids in Saccharomyces cerevisiae cultures induce expression of intracellular 
metal metabolism genes regulated by Aft1p. FEMS Yeast Res 2006, 6:924-936.

30. Lawrence CL, Botting CH, Antrobus R, Coote PJ: Evidence of a new role for the high-osmolarity glycerol mitogen-activated protein kinase pathway in yeast: regulating adaptation to citric acid stress. Mol Cell Biol 2004, 24:3307-3323.

31. Martinez-Munoz GA, Kane P: Vacuolar and plasma membrane proton pumps collaborate to achieve cytosolic $\mathrm{pH}$ homeostasis in yeast. J Biol Chem 2008, 283:20309-20319.

32. Warnecke T, Gill RT: Organic acid toxicity, tolerance, and production in Escherichia coli biorefining applications. Microb Cell Fact 2005, 4:25.

33. Balzer GJ, Thakker C, Bennett GN, San KY: Metabolic engineering of Escherichia coli to minimize byproduct formate and improving succinate productivity through increasing NADH availability by heterologous expression of $\mathrm{NAD}(+)$-dependent formate dehydrogenase. Metab Eng 2013, 20:1-8.

34. Litsanov B, Brocker M, Bott M: Toward homosuccinate fermentation: metabolic engineering of Corynebacterium glutamicum for anaerobic production of succinate from glucose and formate. Appl Environ Microbiol 2012, 78:3325-3337.

35. Piganeau M, Ghezraoui H, De Cian A, Guittat L, Tomishima M, Perrouault L, Rene O, Katibah G, Zhang L, Holmes M, Doyon Y, Concordet JP, Giovannangeli C, Jasin M, Brunet E: Cancer translocations in human cells induced by zinc finger and TALE nucleases. Genome Res 2013, 23:1182-1193.

36. Mali P, Yang LH, Esvelt KM, Aach J, Guell M, DiCarlo JE, Norville JE, Church GM: RNA-guided human genome engineering via Cas9. Science 2013, 339:823-826.

37. Kim Y, Kweon J, Kim A, Chon JK, Yoo JY, Kim HJ, Kim S, Lee C, Jeong E, Chung E, Kim D, Lee MS, Go EM, Song HJ, Kim H, Cho N, Bang D, Kim JS: A library of TAL effector nucleases spanning the human genome. Nat Biotechnol 2013, 31:251-258.

38. Dicarlo JE, Norville JE, Mali P, Rios X, Aach J, Church GM: Genome engineering in Saccharomyces cerevisiae using CRISPR-Cas systems. Nucleic Acids Res 2013, 41:4336-4343.

39. Cong L, Ran FA, Cox D, Lin SL, Barretto R, Habib N, Hsu PD, Wu XB, Jiang WY, Marraffini LA, Zhang F: Multiplex genome engineering using CRISPR/ Cas systems. Science 2013, 339:819-823.

40. Gietz RD, Schiestl RH, Willems AR, Woods RA: Studies on the transformation of intact yeast cells by the LiAc/SS-DNA/PEG procedure. Yeast 1995, 11:355-360.

41. Higuchi R, Krummel B, Saiki RK: A general method of in vitro preparation and specific mutagenesis of DNA fragments: study of protein and DNA interactions. Nucleic Acids Res 1988, 16:7351-7367.

42. Shao Z, Zhao H, Zhao H: DNA assembler, an in vivo genetic method for rapid construction of biochemical pathways. Nucleic Acids Res 2009, 37:e16.

43. Liang J, Ning JC, Zhao H: Coordinated induction of multi-gene pathways in Saccharomyces cerevisiae. Nucleic Acids Res 2013, 41:e54.

44. Teste MA, Duquenne M, Francois JM, Parrou JL: Validation of reference genes for quantitative expression analysis by real-time RT-PCR in Saccharomyces cerevisiae. BMC Mol Biol 2009, 10:99.

\section{Submit your next manuscript to BioMed Central and take full advantage of:}

- Convenient online submission

- Thorough peer review

- No space constraints or color figure charges

- Immediate publication on acceptance

- Inclusion in PubMed, CAS, Scopus and Google Scholar

- Research which is freely available for redistribution

Submit your manuscript at www.biomedcentral.com/submit 